\title{
Phylogenetic analysis of TALE superclass homeobox genes in amphipod crustaceans
}

\author{
Wai Hoong Chang ${ }^{1}$ and Alvina G. Lai ${ }^{1, \bowtie}$ \\ ${ }^{1}$ Institute of Health Informatics, University College London, London, United Kingdom
}

\begin{abstract}
TALE class genes are a group of developmentally conserved transcription factors found in animals. Here, we describe the identification and phylogenetic analysis of TALE class genes in amphipod crustaceans. We identified 241 putative TALE class genes from 56 amphipod crustacean species. Phylogenetic analysis of the genes revealed six subclasses. We provide a list of FASTA sequences of the genes identified. Results from this work may inform future evolutionary and comparative genomics studies on animal development.
\end{abstract}

Organismal animal biology | crustacean homeobox genes | TALE class genes | amphipods | phylogenetic analysis

Correspondence: alvina.lai@ucl.ac.uk

\section{Introduction}

Animals exhibit remarkably phenotypic diversity underpinned by genetic innovations that influence developmental processes. The specification of body plans in animals is regulated by a conserved bilaterian genetic toolkit that encodes a collection of transcription factors and their target cis-regulatory modules found within large gene regulatory networks evolving at different rates (1). These genetic precursors have been discovered in ancient clades such as in choanoflagellates and non-bilaterian animals, suggesting their role during the early evolution of bilaterians (2).

Among the developmental gene families are a highly conserved group of homeodomain-containing transcription factors known for their roles in body plan patterning. Homeodomain proteins are characterised by the presence of a conserved DNA-binding region known as the homeodomain that are seen in Homeobox proteins (3). Homeobox genes consist of a large family of genes subdivided into 11 gene classes in animals (4). Homeobox genes have been widely characterised in a range of model organisms (5). However, systematic characterisation of this gene family is currently lacking in non-model animals. Here, we present the identification and phylogenetic analyses of the three amino acid loop extension (TALE) homeobox genes in amphipod crustaceans.

\section{Methods}

To identify TALE class genes, we previously performed BLAST searches using transcriptome datasets of $56 \mathrm{am}-$ phipod crustacean species retrieved from the European $\mathrm{Nu}-$ cleotide Archive $(6,7)$ (Figure 1). Reference sequences of TALE class genes were downloaded from the NCBI database. We performed tBLASTn searches against the crustacean transcriptomes using the reference sequences with blocks substitution matrices BLOSUM45 and BLOSUM62. BLAST results were filtered for unique hits and by e-value of $<10-5$. Reciprocal BLAST was performed against the GenBank non-redundant (nr) database. Redundant transcripts having at least $98 \%$ identity were collapsed using the CDHIT tool. The HMMER hmmscan tool was used to search against profile hidden Markov model (HMM) libraries to identify Pfam homeodomains (8). Multiple sequence alignment was performed using the MAFFT tool (9). Phylogenetic tree was constructed from the alignment using RAxML WAG $+\mathrm{G}$ model to generate a maximum likelihood tree (10).

\section{Results}

We employed transcriptome datasets from 56 amphipod crustacean species. From these datasets, we identified 241 putative TALE class genes using BLAST and profile HMM homology searches. Phylogenetic analyses of TALE class genes revealed that the genes can be further divided into six subclasses: Tgif, Meis, Pknox, Irx, Mkx and Pbx. The tree topology of amphipod TALE class orthologs is depicted in Figure 2. Fasta sequences are provided as Supplementary data 1.

\section{Conclusion}

TALE class genes identified from amphipod crustaceans demonstrated conserved patterns of evolution. Availability of the gene sequences may contribute to current and future research focusing on elucidating and understanding evolutionary processes in non-model organisms.

\section{Bibliography}

1. Eric H Davidson and Douglas $\mathrm{H}$ Erwin. Gene regulatory networks and the evolution of animal body plans. Science, 311(5762):796-800, 2006.

2. Douglas H Erwin. Early origin of the bilaterian developmental toolkit. Philosophical Transactions of the Royal Society B: Biological Sciences, 364(1527):2253-2261, 2009.

3. Samir Merabet and Brigitte Galliot. The tale face of hox proteins in animal evolution. Frontiers in genetics, 6:267, 2015.

4. Steven M Hrycaj and Deneen M Wellik. Hox genes and evolution. F1000Research, 5, 2016.

5. Jordi Garcia-Fernàndez. The genesis and evolution of homeobox gene clusters. Nature Reviews Genetics, 6(12):881-892, 2005.

6. Wai Hoong Chang and Alvina G Lai. A tale of shrimps: Genome-wide survey of homeobox genes in 120 species from diverse crustacean taxa. F1000Research, 7, 2018.

7. Wai Hoong Chang and Alvina G Lai. Genome-wide analyses of the bhlh superfamily in crustaceans: reappraisal of higher-order groupings and evidence for lineage-specific duplications. Royal Society open science, 5(3):172433, 2018.

8. Simon C Potter, Aurélien Luciani, Sean R Eddy, Youngmi Park, Rodrigo Lopez, and Robert D Finn. Hmmer web server: 2018 update. Nucleic acids research, 46(W1):W200W204, 2018.

9. Kazutaka Katoh and Daron M Standley. Mafft multiple sequence alignment software version 7: improvements in performance and usability. Molecular biology and evolution, 30(4):772$780,2013$.

10. Alexandros Stamatakis. Raxml version 8: a tool for phylogenetic analysis and post-analysis of large phylogenies. Bioinformatics, 30(9):1312-1313, 2014. 
bioRxiv preprint doi: https://doi.org/10.1101/2021.08 10.455793: this version posted Auqust 10,2021. The copyright holder for this preprint (which was not certified by peer review) is the author/funder, who has granted bioRxiv a license to display the preprint in perpetuity. It is made available under aCC-BY-NC-ND 4.0 International license.

\begin{tabular}{|c|c|}
\hline SPECIES NAME & INFRAORDER \\
\hline Acanthogammarus godlewskii & Gammarida \\
\hline Asprogammarus rhodophthalmus & Gammarida \\
\hline Boeckaxelia potanini & Gammarida \\
\hline Brachyuropus grewingkii & Gammarida \\
\hline Brandtia latissima & Gammarida \\
\hline Carinurus bicarinatus & Gammarida \\
\hline Cornugammarus maximus & Gammarida \\
\hline Crypturopus inflatus & Gammarida \\
\hline Echiuropus macronychus & Gammarida \\
\hline Eucarinogammarus wagii & Gammarida \\
\hline Eulimnogammarus cruentus & Gammarida \\
\hline Eulimnogammarus cyaneus & Gammarida \\
\hline Eulimnogammarus czerskii & Gammarida \\
\hline Eulimnogammarus marituji & Gammarida \\
\hline Eulimnogammarus messerschmidtii & Gammarida \\
\hline Eulimnogammarus similis & Gammarida \\
\hline Eulimnogammarus testaceus & Gammarida \\
\hline Eulimnogammarus ussolzewii & Gammarida \\
\hline Eulimnogammarus verrucosus & Gammarida \\
\hline Eulimnogammarus violaceus & Gammarida \\
\hline Eulimnogammarus viridulus & Gammarida \\
\hline Eulimnogammarus vittatus & Gammarida \\
\hline Gammarus chevreuxi & Gammarida \\
\hline Gammarus lacustris & Gammarida \\
\hline Garjajewia dershawini & Gammarida \\
\hline Gmelinoides fasciatus & Gammarida \\
\hline Heterogammarus sophianosii & Gammarida \\
\hline Hyalellopsis carinata & Gammarida \\
\hline Hyalellopsis costata & Gammarida \\
\hline Hyalellopsis grisea & Gammarida \\
\hline Hyalellopsis setosa & Gammarida \\
\hline Hyalellopsis stebbingi & Gammarida \\
\hline Linevichella vortex & Gammarida \\
\hline Macropereiopus parvus & Gammarida \\
\hline Micruropus glaber & Gammarida \\
\hline Micruropus parvulus & Gammarida \\
\hline Micruropus wahlii & Gammarida \\
\hline Odontogammarus calcaratus & Gammarida \\
\hline Ommatogammarus albinus & Gammarida \\
\hline Ommatogammarus flavus & Gammarida \\
\hline Oxyacanthus curtus & Gammarida \\
\hline Oxyacanthus flavus & Gammarida \\
\hline Oxyacanthus sowinskii & Gammarida \\
\hline Pachyschesis branchialis & Gammarida \\
\hline Palicarinus puzyllii & Gammarida \\
\hline Pallasea cancellus & Gammarida \\
\hline Pallasea grubei & Gammarida \\
\hline Pallaseopsis kessleri & Gammarida \\
\hline Parapallasea borowskii & Gammarida \\
\hline Parapallasea wosnessenskii & Gammarida \\
\hline Pentagonurus dawydowi & Gammarida \\
\hline Poekilogammarus pictoides & Gammarida \\
\hline Melita plumulosa & Hadziida \\
\hline Hyalella azteca & Talitrida \\
\hline Parhyale hawaiensis & Talitrida \\
\hline Talitrus saltator & Talitrida \\
\hline
\end{tabular}

Fig. 1. List of amphipod species analysed in this study. 
bioRxiv preprint doi: https://doi.org/10.1101/2021.08.10.455793; this version posted Auqust 10,2021 . The copyright holder for this preprint (which was not certified by peer review) is the author/funder, who has granted bioRxiv a license to display the preprint in perpetuity. It is made available under aCC-BY-NC-ND 4.0 International license.

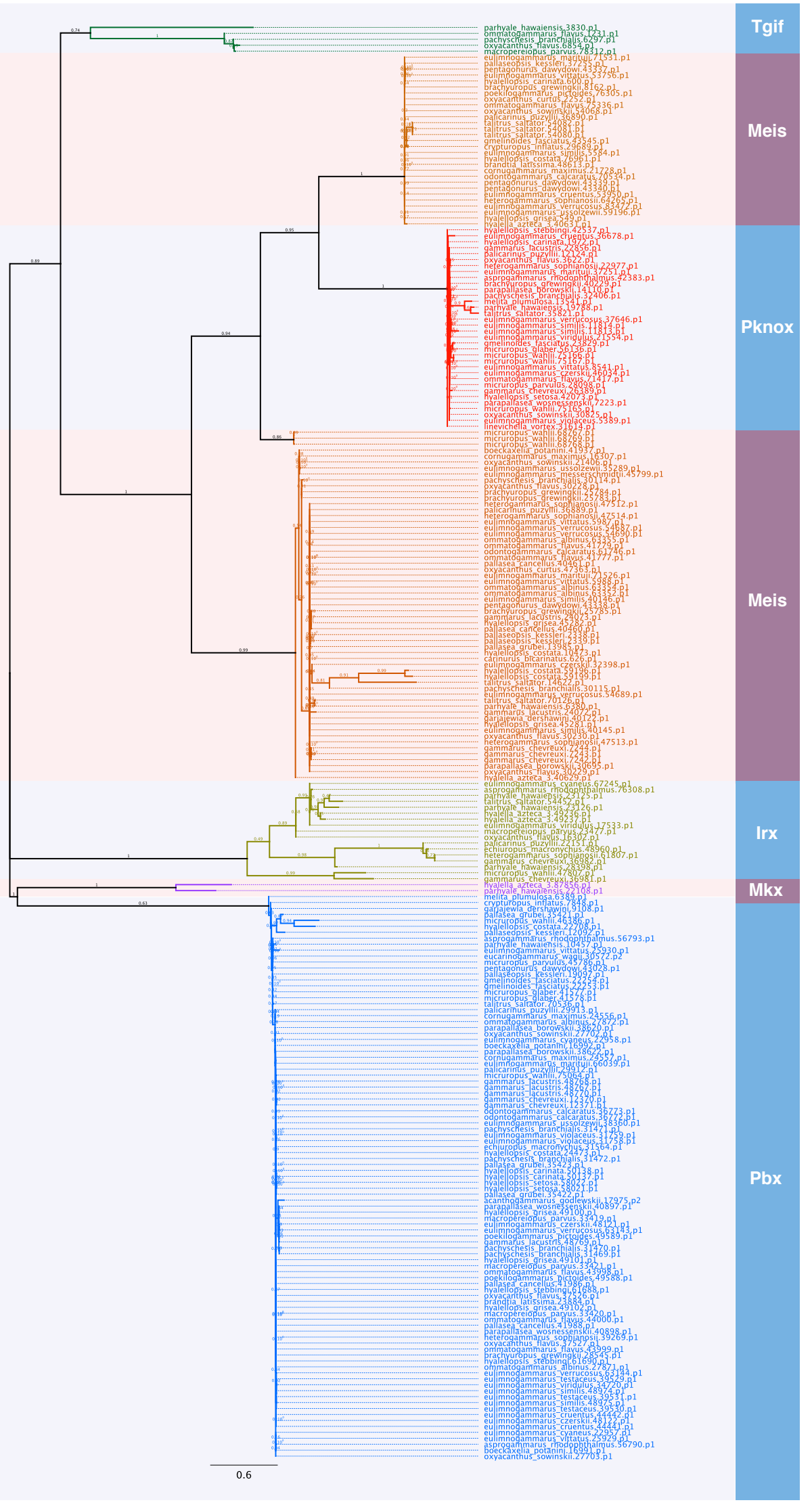

Fig. 2. Maximum likelihood tree of TALE class genes in amphipod crustaceans. 